\title{
The Correlation of Tumor Budding Index with Clinicopathology Parameters on Invasive Breast Carcinoma No Special Type
}

\author{
Septina Indriani Saragih", Betty*, Jessy Chrestella* \\ * Department of Anatomical Pathology, Faculty of Medicine, Universitas Sumatera Utara, Medan, Indonesia. *Corresponding Author
}

DOI: 10.29322/IJSRP.11.12.2021.p12041

http://dx.doi.org/10.29322/IJSRP.11.12.2021.p12041

\begin{abstract}
Background: Invasive breast carcinoma no special type (NST) is the most common type of cancer, making up about $40-75 \%$ of invasive breast cancers. Conventional histopathology prognostic indicators including histology type, tumor size, lymph node involvement, grade, hormone receptor expression, etc. still play an important role in the estimated prognosis in breast carcinoma. Tumors bud are an important step in tumor invasion and metastasis and have attracted interest as a marker of prognosis. Research on the role of tumor budding in breast cancer is still limited.

Research Objective: Analyzes the correlation between tumors budding and clinicolopathology parameters that include tumor size, lymph node involvement, histological grade, LVI, and immunohistochemical profile in invasive breast carcinoma NST.

Material and Methods: This study is an analytical study with a cross sectional approach in 42 samples of paraffin block patients diagnosed histopathologically as invasive breast carcinoma NST. Then, a re-cutting of the paraffin block. Assessment of peritumoral tumor budding is categorized as $\leq 20$ buds/10LPB (low grade) and > 20 buds/10LPB (high grade) with H\&E staining and 400x enlargement. The correlations between tumor budding index and clinicopathology parameters in invasive breast carcinoma NST was statistically tested.

Result: The most age was 50-59 years, with an average age of 52.52 years. There is a significant association between tumor budding index and several clinicopathology parameters, such as grade, LVI, and immunochemical profile. As for tumor size and lymph node involvement did not show a significant association. The most widely found tumor budding index is high grade buds as much as $85.7 \%$.

Conclusion: Reporting of tumor budding results in invasive breast carcinoma of NST can be one of the prognostic criteria that can be applied in routine examinations.
\end{abstract}

Keywords: tumor budding, invasive breast carcinoma NST, prognosis.

\section{INTRODUCTION}

$\mathrm{B}_{\mathrm{r}}$ world, with $2,088,849$ new cases (11.6\%) with a mortality rate of
$626,679(6.6 \%)$ reported in 2018. ${ }^{1,2,3}$ Breast carcinoma is the fifth leading cause of death from carcinoma in the world and the second most common cause of death from carcinoma in women in the United States, after lung cancer. About 1 in 8 women in the United States or about $12 \%$ have invasive breast cancer. According to the American Cancer Society in 2020, there are an estimated 276,480 new cases of invasive breast carcinoma and about 42,170 are expected to die by 2020 from breast carcinoma. ${ }^{4.5}$

In Indonesia the prevalence of breast carcinoma based on data from Global Burden Cancer (GLOBOCAN) 2018, showed that breast carcinoma occupies the first most common carcinoma in women with 58,256 new cases $(30.9 \%)$ and became the leading cause of death in women with 22,692 (11.0\%). Based on data from Basic Health Research Data in Indonesia which until now there has been no update of data, the highest prevalence of breast carcinoma occurred in 2013 at $0.5 \%$, where D.I Yogyakarta Province has the highest prevalence of breast carcinoma, which is $2.4 \%$, while North Sumatra has a prevalence of breast carcinoma of $0.4 \%$.

Breast carcinoma is also still the first type of carcinoma found in Dharmais cancer hospital for the last 4 years until 2013, with the number of new cases (711-819 cases), and the number of deaths from carcinoma continues to grow (93-217 cases). ${ }^{7}$ Over the past 5 years, breast carcinoma case data was obtained at Haji Adam Malik Hospital, namely: in 2014 there were 1181 cases, in 2015 it was 969 cases, in 2016 it was 915 cases, and in 2017 it was 976 cases. ${ }^{8}$

Breast carcinoma is a heterogeneous disease both clinically and pathologically. The heterogeneity of high breast carcinoma causes management to be not completely satisfactory. ${ }^{9}$ Although molecular and genomic assessments have emerged, conventional prognostic indicators of histopathology including histological type, tumor size, lymph node involvement, grade, hormone receptor expression, etc. still play an important role in the estimated prognosis of breast carcinoma. ${ }^{10.11}$

Tumor buds are an important step in tumor invasion and metastasis and in recent years have attracted interest as a marker of prognosis in colorectal cancer, head and neck squamous cell carcinoma, breast cancer, esophageal cancer, gastric cancer,and cervical cancer. Tumor buds are the presence of a single tumor cell or small group of tumors on the front of the invading tumor. ${ }^{12.13}$ The number of cells in tumor budding based on the 
International Tumor Budding Consensus Conference (ITBCC) amounted to less than five tumor cells or up to 4 cells. Tumor buds are associated as part of epithelial mesenchymal transition (EMT), in which tumor cells have the ability to migrate with loss of adhesion and polarity between cells as well as invasion that are characteristic of mesenchymal cells. EMT and its reverse process, mesenchymal epithelial transition (MET), are physiological processes that play a role during embryonic development, wound healing and tissue repair. Aberrant EMT activation is considered a hallmark of cancer metastasis. ${ }^{14.15}$

Tumor buds are associated with tumor aggressiveness and have shown a correlation with a poor prognosis. This can be assessed by the staining of hematoxylin-eosin (H\&E) which is routinely used and does not require other expensive additional equipment. ${ }^{14.16}$ However, research on the role of tumor budding in breast cancer is still limited. Assessment of tumor budding is still relatively new in Indonesia, especially in Medan, where research on the role of tumor budding in the breast is still limited and the significant prognostic strength of tumor budding in other cancers is the background to detect its role in breast carcinoma. Therefore, on this occasion, the authors wanted to examine the correlation of tumor budding index with various clinicopathology parameters in invasive breast carcinoma NST.

\section{MATERIALS AND METHODS}

This research is an analytical study with a cross sectional approach conducted at the Anatomical Pathology Laboratory of the Faculty of Medicine, University of North Sumatera and the Anatomical Pathology Unit of Haji Adam Malik Medan General Hospital. This research was conducted from November 2020 to September 2021, after receiving approval from the Health Research Ethics Committee of the Faculty of Medicine, University of North Sumatera.

This study sample is a paraffin block from patients who have been diagnosed histopathologically as an invasive breast carcinoma NST that meets the criteria for inclusion and exclusion. Samples are taken using consecutive sampling techniques. Inclusion criteria include adequate clinical data on medical records (age, tumor size, lymph node involvement, and immunohistochemistry profile) as well as representative slide or paraffin preparations, derived from postoperative tissue results diagnosed histopathologically as invasive breast carcinoma NST with H\&E staining.. The exclusion criteria for the study are incomplete medical record data and unrepresentative slides or blocks of paraffin that cannot be reprocessed. Each sample is recut and colored with $\mathrm{H} \& \mathrm{E}$.

Tumor buds are tumor cells that are detached from the body of the main tumor, describing the presence of a single and undifferentiated cancer cell. The assessment of tumor budding assessed is at peritumoral, referring to studies that have been conducted by Kumarguru, where the number of tumor buds is categorized as follows, when $\leq 20$ buds/10 HPF (low grade buds) and $>20$ buds $/ 10 \mathrm{HPF}$ (high grade buds). ${ }^{48}$ The grading system refers to the 2019 WHO classification for breast tumors. ${ }^{24}$ Association tumor budding index with clinicopathology parameters in invasive breast carcinoma NST was statistically tested.

\section{RESULT}

In this study, 42 samples of invasive breast carcinoma NST were obtained at the Laboratory of Anatomical Pathology, Faculty of Medicine, University of North Sumatera and Anatomical Pathology Unit of Haji Adam Malik Medan General Hospital. The most age is 50-59 years, with an average age of 52.52 years. Tumor size was more in $\mathrm{T} 2$ as many as 21 cases (50.0\%). Lymph nodes were found in 29 cases $(69.0 \%)$. LVI was found in 28 cases $(66.7 \%)$, grade was found to be most in grade 3 at 20 cases $(47.6 \%)$, and immunohistochemistry profile was found in Luminal A at 14 cases $(33.3 \%)$. Tumor budding most found high grade buds by $85.7 \%$ (Table 1 ).

Table 1. Characteristic of the study sample based on age, tumor

size, lymph node involvement, LVI, histological grade, and immunohistochemistry profile in invasive breast carcinoma NST

\begin{tabular}{|c|c|c|}
\hline Characteristics & $(n=42)$ & Percentage (\%) \\
\hline \multicolumn{3}{|l|}{ Age (years old): } \\
\hline $30-39$ & 4 & 9,5 \\
\hline $40-49$ & 12 & 28,6 \\
\hline $50-59$ & 15 & 35,7 \\
\hline$>59$ & 11 & 26,2 \\
\hline \multicolumn{3}{|l|}{ Tumor size } \\
\hline T1 & 2 & 4,8 \\
\hline T2 & 21 & 50,0 \\
\hline T3 & 17 & 40,4 \\
\hline T4 & 2 & 4,8 \\
\hline \multicolumn{3}{|l|}{ Lymph node } \\
\hline No & 13 & 31,0 \\
\hline Present & 29 & 69,0 \\
\hline \multicolumn{3}{|l|}{ LVI } \\
\hline Negative & 14 & 33,3 \\
\hline Positive & 28 & 66,7 \\
\hline \multicolumn{3}{|l|}{ Grade } \\
\hline Grade 1 & 5 & 11,9 \\
\hline Grade 2 & 17 & 40,5 \\
\hline Grade 3 & 20 & 47,6 \\
\hline \multicolumn{3}{|l|}{ Imunohistochemistry profile } \\
\hline Luminal $\mathrm{A}$ & 14 & 33,3 \\
\hline Luminal B, HER2 $(-)$ & 8 & 19,1 \\
\hline Luminal B, HER2 $(+)$ & 9 & 21,4 \\
\hline Non Luminal & 9 & 21,4 \\
\hline TNBC & 2 & 4,8 \\
\hline
\end{tabular}
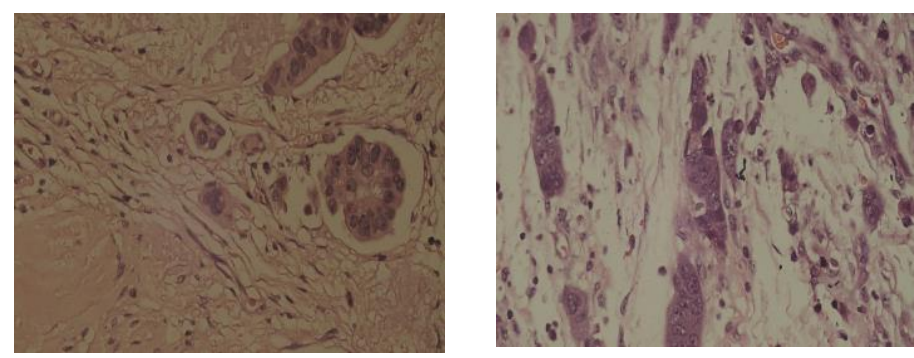

Figure 1. Low grade buds (H\&E, 400X). B. High grade buds (H\&E, 400X).

In this study, it was assessed the correlation between tumor budding index and tumor size in invasive breast carcinoma NST. The study showed a not significant correlation between tumor budding index and tumor size (p-value=0.079) (Table 2).

Table 2. The correlation between tumor budding index and tumor size in invasive breast carcinoma NST

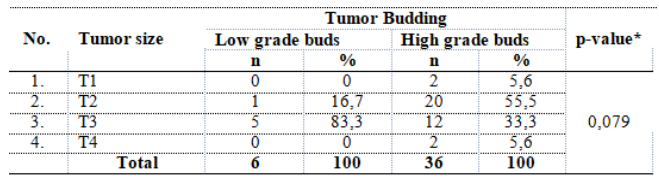

The study also assessed the correlation between tumor budding index and lymph node involvement in invasive breast carcinoma NST. The study showed not significant correlation 
between tumor budding index and lymph node involvement ( $\mathrm{p}$ value $=0.647)($ Table 3$)$.

Table 3. The correlation between tumor budding index and lymph node involvement in invasive breast carcinoma NST.

\begin{tabular}{|c|c|c|c|c|c|c|}
\hline \multirow{3}{*}{ No. } & \multirow{3}{*}{ Lymph node } & \multicolumn{4}{|c|}{ Tumor Budding } & \multirow{3}{*}{ p-value ${ }^{*}$} \\
\hline & & \multicolumn{2}{|c|}{ Low grade buds } & \multicolumn{2}{|c|}{ High grade buds } & \\
\hline & & $\mathrm{n}$ & $\%$ & $\mathbf{n}$ & $\%$ & \\
\hline 1. & Negative & 1 & 16,7 & 12 & 33,3 & \multirow[t]{3}{*}{0,647} \\
\hline 2. & Positive & 5 & 83,3 & 24 & 66,7 & \\
\hline & Total & 6 & 100 & 36 & 100 & \\
\hline
\end{tabular}

In this study, it assessed the corrrelation between tumor budding index and grading in invasive breast carcinoma NST. Studies have shown a significant correlation between tumor budding index and grading (p-value=0.0001) (Table 4).

Table 4. The correlation between tumor budding index and grading in invasive breast carcinoma NST

\begin{tabular}{|c|c|c|c|c|c|c|}
\hline \multirow{3}{*}{ No. } & \multirow{3}{*}{ Grade } & \multicolumn{4}{|c|}{ Tumor Budding } & \multirow{3}{*}{ p-value* } \\
\hline & & \multicolumn{2}{|c|}{ Low grade buds } & \multicolumn{2}{|c|}{ High grade buds } & \\
\hline & & $\mathbf{n}$ & $\%$ & n & $\%$ & \\
\hline 1. & Grade 1 & 5 & 83,3 & 0 & 0 & \multirow{4}{*}{0,0001} \\
\hline 2. & Grade 2 & 1 & 16,7 & 16 & 44,4 & \\
\hline 3. & Grade 3 & 0 & 0 & 20 & 55,6 & \\
\hline & Total & 6 & 100 & 36 & 100 & \\
\hline
\end{tabular}

In this study, it assessed the correlation between budding tumor budding index and LVI in invasive breast carcinoma NST. Studies have shown a significant association between budding tumor budding index and LVI (p-value=0.011) $($ Table 5)

Table 5. The correlation between tumor budding index and LVI in invasive breast carcinoma NST.

\begin{tabular}{|c|c|c|c|c|c|c|}
\hline \multirow{3}{*}{ No. } & \multirow{3}{*}{ LVI } & \multicolumn{4}{|c|}{ Tumor Budding } & \multirow{3}{*}{ p-value* } \\
\hline & & \multicolumn{2}{|c|}{ Low grade buds } & \multicolumn{2}{|c|}{ High grade buds } & \\
\hline & & $\mathrm{n}$ & $\%$ & n & $\%$ & \\
\hline & Negative & 5 & 83,3 & 9 & 25,0 & \multirow{3}{*}{0,011} \\
\hline 2. & Positive & 1 & 16,7 & 27 & 75,0 & \\
\hline & Total & 6 & 100 & 36 & 100 & \\
\hline
\end{tabular}

In this study, it assessed the correlation between tumor budding index and immunohistochemistry profile in invasive breast carcinoma NST. The study showed a significant association between the tumor budding index and the immunohistochemistry profile $(\mathrm{p}$-value $=0.0067)$ (Table 6).

Table 6 . The correlation between tumor budding index and immunohistochemistry profile in invasive breast carcinoma NST.

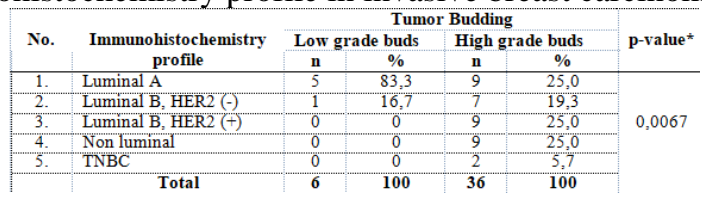

\section{DISCUSSION}

In this study the number of samples diagnosed as invasive breast carcinoma NST was 42 samples, the most patients aged 50-59 years, with an average of 52.52 years, the youngest age 31 years and the oldest age 75 years. Salhia et al. in 2015 it was found that invasive breast carcinoma NST occurred at the average age of patients at diagnosis was 61 years with an age range of 32-91 years. ${ }^{46}$ Gujam et al. in 2015 stated that invasive breast carcinoma NST occurred in women aged $>50$ years about $70 \% .{ }^{52}$ Sriwidyani et al. in 2016 found that the average age of patients aged 48.6 years with an age range in his study of 23-74 years. ${ }^{49}$ Kumarguru et al. in 2020 found that the average age of patients is 53.14 years, with an age range of $24-77$ years. ${ }^{48}$ This study found that the age of breast carcinoma sufferers is at an advanced age that occurs in women over 50 years. Reportedly a young patient in this study, which is 31 years old.

Invasive breast carcinoma NST, can be caused by various causes, including due to unhealthy lifestyle and genetic factors. In a less healthy lifestyle, combined with lack of physical exercise and a family history increases the risk of breast carcinoma. $^{24,26}$ Therefore, because of these risk factors, supporting the reason breast carcinoma can occur at a young age.

The size of the tumor is more in T2, which is as much as $50.0 \%$. Research by Liang et al. in 2013 reported that tumor size was highest at T2 (69.8\%). ${ }^{10}$ Masilamani et al. in 2019 reported tumor size at T2 $(49.8 \%) .{ }^{53}$ In this study, tumor size showed no statistical association with tumor budding. Differences in outcomes in this study may be attributed to differences in the study population and these results also suggest a lack of public awareness to get early checked for breast carcinoma. Delays in diagnosis and treatment of patients who are late result in patients usually coming already in an advanced condition. Differences in the size of this tumor may be related to microenvirontment of a tumor.

Lymph node involvement is one indicator of poor prognosis in the majority of breast carcinoma studies, including in this study, which reported that most invasive breast carcinomas of NST accompanied by lymph node involvement, which is as much as $69.0 \%$. The differences from this study may be due to differences in the study's population.

In this study, $47.6 \%$ of the study sample was grade 3 . The results of this study are in line with research conducted by Gujam et al. in 2015, where they reported as much as $40 \%$ of invasive breast carcinoma NST is grade $3 .^{52}$ Research by Sriwidyani et al. in 2016 also obtained results in line where grading is most found in grade 3 as much as $50 \% .{ }^{49}$ Agarwal et al. in 2019 reported that the most common grade 3 cases were $82 \% .{ }^{17}$ This is likely due to lack of awareness people to do early detection so that breast carcinoma is found at a high grade.

In this study, LVI was found to be $66.7 \%$. The remaining 14 samples were not found LVI $(33.3 \%)$. The results of this study are in line with research conducted by Sriwidayani et al. in 2016, where they found LVI as much as $75.71 \% .^{49}$ Whereas, in research conducted by Renuka et al. in 2019 found LVI as much as $74 \% .{ }^{54}$ After statistical test analysis, a significant association was found between the tumor budding index and LVI in this study. The results of this study are not much different from previous studies. Even the results of a meta-analysis conducted by Lloyd et al. in 2020 also showed a significant association between budding tumors and LVI. ${ }^{60}$ The association of high grade buds with the presence of LVI can be considered an indicator of poor prognosis factors in breast carcinoma. This image can be helpful in therapy and decision-making and can be incorporated into reporting on invasive breast carcinoma NST.

Based on the results of immunoohistochemical profile examination, the most luminal A subtypes were obtained in this study, which was $33.3 \%$, then consecutively luminal B like HER2 positive (21.4\%), non luminal (21.4\%), luminal B like HER2 negative (19.1\%), and the least is TNBC (4.8\%). Salhia et al. in 2015 reported the most luminal A, which was $62.2 \% .46$ Masilamani et al. in 2019 also reported the most luminal A, 
which was $39.3 \% .53 \mathrm{Li}$ et al. in 2017 has shown that tumors budding are significantly associated with decreased disease-free survival in breast carcinoma patients. Assessment of budding tumors can provide useful information for treatment management in breast carcinoma, especially in breast carcinoma $\mathrm{ER}(+) /$ HER2(-) and so that it can be used in routine reporting..$^{60,63 .}$ Differences in results in this study may be attributed likely due to differences in the study population.

In this study, the most tumors budding were high grade buds as much as $85.7 \%$, compared to low grade buds only as much as $14.3 \%$. Salhia et al. (2015) reported that the most tumors budding were high grade buds, which was $79.7 \% .46$ Masilamani et al. (2019) reported that the most tumors budding were high grade buds, which is as much as $80.4 \% .^{53}$ Prognostic value of tumor budding in breast carcinoma has been evaluated in a number of studies. In recent years tumor budding research began to develop and was introduced as a possible tool for identifying poor clinical outcomes in patients and finding budding tumors as independent predictors. ${ }^{48,60}$

\section{CONCLUSION}

After the study was conducted, we underlined some of the following conclusions:

1. Patients with invasive breast carcinoma NST occur mostly at the age of 50-59 years with the average age of patients is 52.52 years, where the youngest age is 31 years and the oldest age is 75 years.

2. The largest index of tumors budding is high grade buds. The size of the tumor in this study was more in $\mathrm{T} 2$, which is as much as $50.0 \%$. There was no significant association between budding tumor index and tumor size.

3. Most invasive breast carcinomas of NST are accompanied by the involvement of lymph nodes, which is as much as $69.0 \%$. There is no significant association between budding tumor index and lymph node involvement.

4. It found that $47.6 \%$ was grade 3 . There is a significant correlation between tumor budding index and histopathological grading.

5. There was an LVI of $66.7 \%$. There is a significant correlation between tumor budding index and LVI.

6. Obtained the most luminal subtype A in this study then consecutive luminal B like HER2 positive, non luminal, luminal B like HER2 negative and the least is TNBC.

\section{REFERENCE}

[1] WHO. Breast Cancer Today. IARC. http://gco.iarc.fr/today/data/factsheets/cancers/20-Breast-fact-sheet.pdf. Published 2018. Accessed September 18, 2020.

[2] WHO. Globocan 2018 Latest global cancer data-IARC. http://www.iarc.fr/infographics/globocan-2018-latest-global-cancer-data. Published 2018. Accessed September 18, 2020.

[3] Bray F, Ferlay J, Soerjomataram I, Siegel RL, Torre LA, Jemal A. Global cancer statistic 2018: GLOBOCAN estimates of incidence and mortality worldwide for 36 cancer in 185 countries. CA Cancer J Clin.2018;68(6):394424. doi:10.3322/caac. 21492
[4] American Cancer Society. How Common is Breast Cancer? http://www.cancer.org/cancer/breast-cancer/about/how-common-is-breastcancer.html. Published January 2020. Accessed September 18, 2020.

[5] American Cancer Society. Cancer Facts \& Figures 2020. http://www.cancer.org/research/cancer-facts-statistics/all-cancer-factsfigures/cancer-facts-figures-2020.html. Published 2020. Accessed September 18,2020

[6] WHO.Indonesia.IARC

http://gco.iarc.fr/today/data/factsheets/populations/360-indonesia-factsheets.pdf. Published 2018. Accessed September 18, 2020.

[7] Kemenkes RI. Infodatin. Jakarta; 2018 https://www.kemkes.go.id/download.php?file=download/pusdatin/infodatin/i nfodatin-disabilitas.pdf. Accessed November 9, 2020

[8] Sinaga D, Simanjuntak E, Tarigan F. Survivor Kanker Payudara Studi Kualitatif tentang Upaya Penderita Kanker Payudara Untuk Mempertahankan Kualitas Hidupnya di RSUP H. Adam Malik Medan Tahun 2019. J ILM Simantek. 2019;3(3). doi:10.1007/s11764-011-0193-7.

[9] PP Rosen. Rosen's Breast Pathology. Philadelphia: Lippincott Williams \& Wilkins; 2001.

[10] Liang F, Cao W, Wang Y, Li L, Zhang G, Wang Z. The prognostic value of tumor budding in invasive breast cancer. Pathol Res Pract. 2013;209(5):269. 275. doi:10.1016/j.prp.2013.01.009.

[11] Oakman C, Santarpia L, A DL. Breast cancer assessment tools and optimizing adjuvant theraphy. Nat Rev Clin Oncol. 2010;7:725-732. https://www.nature.com/articles/nrclinonc.2010.170. Accessed December 9, 2020.

[12] Fauzi MFA, Chen W, Knight D, Hampel H, Frankel WL, Gurcan MN. Tumor Budding Detection System in Whole Slide Pathology Images. J Med Syst. 2020;44(2):1-10. doi:10.1007/s10916-019-1515-y.

[13] Lugli A, Kirsch R, Ajioka Y, Bosman F, Cathomas G, Dawson H, et al Recommendations for reporting tumor budding in colorectal cancer based on the International Tumor Budding Consensus Conference (ITBCC) 2016 Mod Pathol. 2017;30(9):1299-1311. doi:10.1038/modpathol.2017.46.

[14] Grigore A, Jolly m, Jia D, Farach-Carson M, Levine H. Tumor Budding: The Name is EMT. Partial EMT. J Clin Med. 2016;5(5):51. doi:10.3390/jcm5050051.

[15] Zlobec I, Lugli A. Epithelial mesemchmal transition and tumor budding in aggressive colorectal cancer : tumor budding as oncotarget. Oncotarget.2010;65(5):587-594. doi:10.18632/oncotarget.199.

[16] Almangush A, Salo T, Hagström J, Leivo I. Tumor budding in head and neck squamous cell carcinoma-a systematic review. Histopathologyl 2014;65(5):587-594. doi:10.1111/his.12471

[17] Agarwal R, Khurana N, Singh T. Tumor budding in infiltrating breast carcinoma: Correlation with known clinicopathological parameters and hormone receptor status. Indian J Pathol Microbiol. 2019;62(2):222225.http://www.ijpmonline.org/article.asp?issn $=0377$ -

$4029 ;$ year $=2019 ;$ volume $=62 ;$ issue $=2 ;$ spage $=222 ;$ epage $=225 ;$ aulast $=$ Agarwal Accessed December 9, 2020.

[18] Waugh A, Grant A. Anatomy and Physiology in Health and Illness. Elsevier Limited; 2004

[19] Hall JA, Knaus JV. The Encylopedia of Visual Medicine Series: An Atlas of Breast Disease. USA: The Pathenon Publishing Group. 2005.

[20] McGuire KP. Breast disease diagnose and pathology. Springer Nat Switz AG. 2019;2(1):2-6.

[21] Molavi DW. Breast. In: The Practice of Surgical Pathology. Cham:Springer International Publishing; 2018:198-209. doi:10.1007/978-3-319-59211-4_19

[22] VP E. DiFiore's Atlas of Histology with Functional Correlations. $12^{\text {th }}$ ed. Philadelphia: Lippincott Williams \& Wilkins; 2013.

[23] Fan F, Thomas PA. Common Benign Condition of Low Concern. In:Breast Cancer and Its Precursor Lesions. Humana Press; 2011:7-12. doi:10.1007/978-1-60327-154-7_2.

[24] Rakha EA, Allison KH, Ellis IO, Horri R, masuda S, Penault-Llorca F. Invasive breast carcinoma: general overview. In: Cree IA, Lokuhetty D, eds. World Health Organization Classification of the Tumors-Breast Tumors. $5^{\text {th }}$ ed. Lyon: IARC Press; 2019:82-89, 102-109.

[25] Sharma D, Shah I, patel S. Late onset hydrocephalus in children with tuberculous meningitis. J Fam Med Prim Care. 2016;5(4):873 doi:10.4103/2249-4863.201145. 
[26] Garcia-Closas M, Gunsoy NB, Chatterjee N. Combined association of genetic and environmental risk factors: Implications for prevention of breast cancer. J Natl Cancer Inst. 2014;106(11). doi:10.1093/jnci/dju305

[27] Yavas G, Karabagli P, Murat •, Cagdas A•, Ozlem Ata Y•. HER-2 positive primary solid neuroendocrine carcinoma of the breast: a case report and review of the literature. Springer. 2015;22(4):432-436. doi:10.1007/s12282012-0382-x

[28] Sirous M, Shahnani P, Sirous A. Investigation of Frequency Distribution of Breast Imaging Reporting and Data System (BIRADS) Classification and Epidemiological Factors Related to Breast Cancer in Iran: A 7-year Study (2010-2016). Adv Biomed Res. 2018;7(1):56. doi:10.4103/abr.abr_161_17.

[29] Lai BS, Tsang JY, Poon IK, Shao Y, Chan SK, Tam FK, et al. The Clinical Significance of Neuroendocrine Features in Invasive Breast Carcinomas. 2020;25(9):e1318-e1329. doi:10.1634/theoncologist.2020-0081.

[30] Niu Y, Liao X, Li x, Zhao L. Case Report Breast Carcinoma with osteoclastic giant cells : case report and review of the literature. 2014.7(4):1788-1791.

[31] Sung HJ, Maeng YI, Kim MK, et al. Breast carcinoma with choriocarcinomatous features: A case report. J Breast Cancer. 2013;16(3):349-353. doi:10.4048/jbc.2013.16.3.349.

[32] Zhang X, Liang Y, Wang HY. Invasive ductal carcinoma of the breast associated with extensive melanin melanosis: A case report and review of the literature. Int J Clin Exp Pathol. 2014;7(3):1218-1223.

[33] Bendic A, Bozic M, Durdov MG. Metaplastic breast carcinoma with melanocytic differentiation. Pathol Int. 2009;59(9):676-680. doi:10.1111/j.1440-1827.2009.02426.x.

[34] Shen S Di, Zhong SZ, Wang CZ, Huang WH. Correlation of lymphovascular invasion with clinicopathological factors in invasive breast cancer: A metaanalysis. Int J Clin Exp Med. 2015;8(10):17789-17795.

[35] Song YJ, Shin SH, Cho JS, Park MH, Yoon JH, Jegal YJ. The role of lymphovascular invasion as a prognostic factor in patients with lymph nodepositive operable invasive breast cancer. J Breast Cancer. 2011;14(3):198203. doi:10.4048/jbc.2011.14.3.198.

[36] Kim S, Park HK, Jung HY, Lee SY, Min KW, Kim WY, et al. ERG immunohistochemistry as an endothelial marker for assessing lymphovascular invasion. Korean J Pathol. 2013;47(4):355-364. doi:10.4132/KoreanJPathol.2013.47.4.355.

[37] Crandall CJ, Sehl ME, Crawford SL, Gold EB, Habel LA, Butler LM, et al. Sex steroid metabolism polymorphisms and mammographic density in preand early perimenopausal women. Breast Cancer Res. 2009;11(4). doi:10.1186/bcr2340

[38] Deoghare S, Dombale V, Sarfaraz Ali S, Dalwai A. Study of Estrogen Receptor, Progesterone Receptor and Human Epidermal Growth Factor Receptor Expression by Immunohistochemistry in Breast Carcinoma. 2017. http://www.doi-ds.org/doilink/12.2017-11974847/. Accessed December 11, 2020.

[39] Shah R, Rosso K, David Nathanson S. Pathogenesis, prevention, diagnosis and treatment of breast cancer. World J Clin Oncol. 2014;5(3):283-298. doi:10.5306/wjco.v5.i3.283.

[40] Vrbic S, Pejcic I, Filipovic S, Kocic B, Vrbic M. Current and future antiHER2 therapy in breast cancer. $J$ BUON. 2013;18(1):4-16. https://europepmc.org/article/med/23613383. Accessed December 11, 2020.

[41] Gagliato D de M, Jardim DLF, Marchesi MSP, Hortobagyi GN. Mechanisms of resistance and sensitivity to anti-HER2 therapies in HER2+ breast cancer. Oncotarget. 2016;7(39):64431-64446. doi:10.18632/oncotarget.7043.

[42] Moasser MM, Krop IE. The evolving landscape of HER2 targeting in breast cancer. JAMA Oncol. $2015 ; 1(8): 1154-1161$. doi:10.1001/jamaoncol.2015.2286.

[43] Wolff AC, Hammond ME, Allison KH, Harvey BE, Mangu PB, barlett JM, et al. Human Epidermal Growth factor Receptor 2 testing in Breast Cancer : American Society of Clinical Oncology / College of American Pathologists Clinical Practice Guideline Focused Update. Arch Pathol Lab.2018.

[44] Soliman NA, Yussif SM. Ki-67 as a prognostic marker according to breast cancer molecular subtype. Cancer Biol Med. 2016; 13(4):496-504.

[45] Ahn HJ, Jung SJ, Kim TH, Oh MK, Yoon HK. Differences in clinical outcomes between luminal A and B type breast cancers according to the St. Gallen Consensus 2013. J Breast Cancer. 2015; 18(2):149-59.

[46] Salhia B, Trippel M, Pfaltz, Cihoric N, Grogg A, Ladrach C, et al. High tumor budding stratifies breast cancer with metastatic properties. Breast Cancer Res Treat.2015;150:363-371. doi:10.1007/s10549-015-3333-3.
[47] Voutsadakis IA. Prognostic role of tumor budding in breast cancer. World $J$ Exp Med. 2018;8(2):12-17. doi:10.5493/wjem.v8.i2.12.

[48] Kumarguru B, Ramaswamy A, Shaik S, Karri A, Srinivas V, Prashant B. Tumor budding in invasive breast cancer - An indispensable budding touchstone. Indian J Pathol Microbiol. 2020;63(5):117. doi:10.4103/IJPM.IJPM_731_18.

[49] Sriwidyani NP, Manuaba IBTW, Alit-Artha IG, Mantik-Astawa IN. Tumor Budding in Breast Carcinoma: Relation to E-Cadherin, MMP-9 Expression, and Metastasis Risk. Bali Med J. 2016;5(3):150. doi:10.15562/bmj.v5i3.335.

[50] Sanjaya F, Paulus IB, Sari FP. Potensi MicroRNA10-B dan MicroRNA-155 sebagai modalitas mutakhir dalam deteksi mikrometastasis/Isolated Tumor Cells (ITC) pada kanker payudara stadium dini. Essence of Scientific Medical Journal. 2018;16(1):12-20. http://ojs.unud.ac.id/index.php/essential/article/view/44564. Accessed January 15, 2021.

[51] Kim B, Kim JM, Kang GH, Chang HJ, Kang DW, Kim JH, et al. Standardized Pathology Report for Colorectal Cancer, 2nd Edition. J Pathol Transl Med. 2019;54(1):1-19. doi:10.4132/jptm.2019.09.28.

[52] Gujam FJ, McMillan DC, Mohammed ZM, Edwards J, Going JJ. The relationship between tumor budding, the tumour microenvirontment and survival in patients with invasive ductal breast cancer. $\mathrm{Br} \mathrm{J}$ Cancer. 2015;113(7): 1066-1074. doi : 10.1038/bjc.2015.287.

[53] Masilamani S, P Kanmani. Evaluation of clinicopathologic significance of tumor budding in breast carcinoma. Inter $\mathbf{J}$ of Clin Diagnostic Pathol. 2019;2(1): 171-173. doi : https://doi.org/1033545/pathol.2019.v2.ilc.25.

[54] Gabal SM, Bassam AM, Sedqi ME, Allam RM. Tumour budding and MMP2 expression in breast invasive ductal carcinoma. J Clin Diagnostic Res. 2018;12(5): EC25-EC29. doi https://doi.org/10.7860/JCDR/2018/34941.11540.

[55] Renuka IV, Madhavi K, Premalatha P, Krishnamacharyulu PAV, Vaishnavi R. Tumor budding in invasive carcinoma of breast of No Special Type (NST) : Value as a prognostic factor. J Diagn Pathol Oncol. 2019;4(2): 125-129. doi : https ://doi.org/10.18231/j.jdpo.2019.024.

[56] Ishii G, Ochiai A, Neri S. Phenotypic and functional heterogeneity of cancerassociated fibroblast within the tumor microenvirontment. Adv Drug Deliv Rev. 2016;99:186-196. doi:10.1016/j.addr.2015.07.007.

[57] Kalluri R. The biology and function of fibroblasts in cancer. Nat Publ Gr. 2016;16(9):582-598. doi:10.1038/nrc.2016.73.

[58] Sugimoto H, Mundel TM, Kieran MW, Kalluri R. Identification of fibroblast heterogeneity in the tumor microenvirontment. Cancer Biol Ther. 2006;5(12):1640-1646. doi: 10.4161/cbt.5.12.3354 